\title{
A JUSTIÇA NO BRASIL COLÔNIA
}

THE BRAZILIAN JUDICIAL SYSTEM IN COLONIAL PERIOD

Maria Cristina da Silva Carmignani*

\begin{abstract}
Resumo:
$\mathrm{O}$ artigo retrata o aparato judicial do período colonial brasileiro - seus agentes e órgãos, com suas características e jurisdição - bem como busca compreender o direito aplicado ao longo desse período, especialmente no tocante às fontes do direito português, as denominadas leis gerais.

Palavras-chave: Organização judiciária. Período colonial brasileiro. Fontes do direito. Direito português. Leis gerais.
\end{abstract}

\begin{abstract}
:
This paper presents the judicial system of the Brazilian colonial period - their agents and organizations, with your characteristics and jurisdiction - as well as seeks to understand the Law applied throughout this period, especially regarding the sources of Portuguese law, so called general laws.
\end{abstract}

Keywords: Judicial system. Brazilian colonial period. Sources of law. Portuguese law. General laws.

\section{Introdução}

$\mathrm{O}$ artigo tem por objetivo o estudo da organização jurídica e judiciária no Brasil colonial, até os pródromos da independência, contextualizando-as dentro do sistema político-administrativo em vigor no período e apontando as suas principais características.

Como a evolução das instituições jurídicas não pode ser entendida senão dentro de uma dinâmica que envolva também a estrutura política, social, econômica e cultural, impõe-se também a abordagem desses aspectos para uma melhor compreensão do sistema jurídico.

A importância do presente estudo histórico-jurídico consiste em trazer ao conhecimento, em especial da comunidade acadêmica, a história das instituições jurídicas brasileiras do período inicial de formação da nossa sociedade, proporcionando assim uma melhor compreensão das estruturas jurídicas atuais do Brasil.

Desta forma, iremos mostrar o que foi oriundo da Metrópole portuguesa, transplantado aqui para o Brasil, e o que foi criado especialmente para a colônia, sendo, portanto, direito genuinamente brasileiro.

Professora Doutora de História do Direito da Faculdade de Direito da Universidade de São Paulo. 
O texto a seguir apresentado é fruto de pesquisa que se iniciou quando da comemoração dos 500 anos de Brasil, cujo trabalho foi apresentado em Simpósio comemorativo, ainda de forma embrionária, mas tendo contado com a inestimável contribuição do saudoso mestre e orientador Luiz Carlos de Azevedo (AZEVEDO; CARMIGNANI, 2000), e que se estendeu em razão da abordagem do tema como parte integrante do programa da disciplina de História do Direito Luso-brasileiro, ministrada na graduação da Faculdade de Direito da Universidade de São Paulo, em conjunto com o Professor Titular Ignácio Maria Poveda Velasco.

\section{Contexto histórico}

Acompanhando o impacto da epopeia dos descobrimentos marítimos, o Século XVI trará perspectivas inéditas ao desenvolvimento das atividades humanas: reabilita-se o pensamento, com o retorno à antiguidade clássica, conhece-se significativo impulso nas letras e nas artes, reaviva-se o humanismo, incrementa-se a especulação filosófica; ao mesmo tempo, amplia-se o comércio, difunde-se o conhecimento com a descoberta da imprensa, deslumbra-se o velho mundo com a fascinação e o encantamento das terras distantes, onde aventura e fortuna se confundem, arrebatando os que se arriscam na empreitada.

Portugal está assim como no entremeio do confronto: se demora, ainda, em aceitar novos contornos, carregado que se acha na mundividência dos senhorios, antecipase às demais nações no arrojo do lance, afrontando o desconhecido e os seus espantos, desde o abismo dos oceanos até a impossibilidade de se habitar nas zonas tórridas.

Nesta conjuntura, sobrelevam as contradições e as dificuldades que daquelas decorrem: o intercâmbio mercantil, que se intensifica, se amealha ininterrupto e crescente surto de progresso, traz consigo não menores problemas de sempre difícil solução; não basta conquistar novos domínios, pois é preciso mantê-los e sustentá-los, tarefa para qual não há como exercitar emigração contínua, dado o escasso contingente populacional que o reino dispõe para tal fim.

Fato é, no entanto, que este empenho se desdobra pelos anos seguintes às grandes descobertas: no Brasil, de forma incipiente e esparsa, no início, para mais tarde obter maior desenvoltura e regramento, com a criação das capitanias hereditárias e com a instalação do governo-geral.

Enquanto isso, na metrópole, rarificam-se as cortes e o rei medieval vai sendo substituído pelo rei absoluto, com o fortalecimento definitivo de sua autoridade; por isso, encorpa-se o aparato administrativo e judicial que o envolve, dignifica e protege, em especial, na edição de uma legislação destinada a lhe garantir o poder, que nele reside e que dele provém. 
Não obstante a numerosa legislação, que nunca cessou de se editar, as três grandes compilações lusitanas, conhecidas como as Ordenações do Reino, constituem o resultado de uma política destinada a fornecer unidade e composição aos ordenamentos jurídicos do Reino. Substituindo as Afonsinas, editadas ainda no século anterior, as Ordenações Manuelinas integram-se a este momento histórico da nação, promulgandose a impressão válida no ano de 1521, poucos meses antes da morte do rei D. Manuel. Seriam, por sua vez, revogadas pelas Filipinas, as quais, no entanto, muito da anterior conservaram, guardando, na essência, o espírito nacional, embora o reino estivesse sob o comando de um monarca espanhol (1603).

Todas elas mantiveram a distribuição da matéria em cinco livros, de um modo geral, assim discriminados no que diz respeito ao conteúdo: I. Regimento dos cargos públicos e atribuições dos funcionários reais; II. Clero e nobreza, direitos do rei, administração fiscal; III. Processo civil; IV. Direito Civil; V. Direito Penal e processo penal.

Cartas de leis, alvarás, provisões, resoluções, portarias, avisos, iriam compor, nos períodos seguintes, o conjunto da legislação complementar, dirigida à matéria fiscal, administrativa e processual, enquanto o Direito Privado seria por via de regra mantido os seus contornos de origem romano-canônica, enriquecido, quando não embaraçado, pela contribuição doutrinária dos praxistas, bem como pela interpretação que lhe desenvolveu a jurisprudência.

Em tais condições, tanto em Portugal, quanto nas terras descobertas e que prosseguiram na sua posse, vigoraram essas leis, transferindo-se para as colônias, por consequência, toda a complicada máquina funcional respectiva, composta de provedores, ouvidores, capitães-mores, oficiais da Fazenda, alcaides encarregados do abastecimento e segurança das praças mais distantes, almotacés e tantos outros agentes do poder público, um elenco apreciável de encarregados da administração, ciosos de suas competências, em especial, quando se tratava de assuntos do erário, já que à coroa interessava a remessa periódica dos impostos arrecadados para a metrópole. Nos pequenos conglomerados urbanos, repete-se, da mesma forma, a conformação secular comunheira, homens-bons e vereadores, com exercício regular nas câmaras, escrivães, cartorários, tesoureiros, oficiais militares e ademais disso, o aparato judiciário, igualmente numeroso na distribuição de cargos e funções.

Este o panorama resumido no qual assentar-se ia a organização jurídica e judiciárias, calcada na legislação reinol, que lhe dava esteio e força. 


\section{Características gerais do direito no Brasil Colônia}

Considerando a condição de dependência em que se achava a colônia, não podia a sua organização jurídica afastar-se muito daquela da metrópole.

Como ressalta Sérgio Buarque de Holanda, recebemos como herança de uma nação ibérica, as nossas instituições, costumes, ideias, servindo Espanha e Portugal de ponte para a comunicação com a Europa, com "tentativa de implantação da cultura européia em extenso território, dotado de condições naturais, se não adversas, largamente estranas à sua tradição milenar". (HOLANDA, 1995, p. 31).

Resultante dessa distinção entre a colônia e a metrópole, a organização vigente em Portugal não poderia ser integralmente adotada no Brasil.

A organização jurídica metropolitana era originária, ou seja, não derivava de nenhuma outra, ao contrário da colonial, que era derivada, devendo seguir os moldes da organização da metrópole.

A organização jurídica da colônia, por sua vez, deveria prover as suas necessidades básicas, com a determinação dos direitos e deveres dos habitantes, organização da administração em seus diversos ramos, instituindo assim o regime administrativo colonial.

Desta forma, todas as leis que regulavam as suprarreferidas necessidades básicas da colônia, deviam ser promulgadas pela metrópole, única entidade que exercia todo poder no território da colônia.

O poder de legislar para a colônia era reservado quase exclusivamente aos competentes órgãos da metrópole, só em determinados casos se permitia que as autoridades locais decretassem atos legislativos, atribuindo-se-lhes um poder legislativo residual.

A legislação emanada para organizar juridicamente a nova coletividade constituída nas colônias, compreendia as leis gerais e as leis especiais, além do direito local, a que passaremos a seguir a descrever.

No entanto, as autoridades portuguesas tinham conhecimento da dificuldade para impor as Leis Gerais do Reino, de forma que "as consequências de uma aplicação irrestrita do direito português no Brasil antolhavam-se devastadoras" (MARCOS; MATHIAS; NORONHA, 2014, p. 125).

Essa dificuldade encontra-se relatada em carta escrita pelo Governador Mem de Sá ao Rei de Portugal, datada de 1560, cujo trecho encontra-se abaixo transcrito:

(...) 6. Eu tevera feitos outras muitas igrejas se tevera com quê. Para isto pedia o poder pedoar as culpas, que aconteceram depois da minha vinda, para apricar as penas a estas obras. Porque as outras da justiça, polas leis do Reino, são, as mais (delas) apricadas aos cativos. Esta terra não se deve nem pode regular pelas leis e estilos do Reino. Se 
V. Alteza não for muito facil em perdoar, não terá gente no Brasil. E porque o eu ganhei de novo, desejo de se ele conservar. (...). (LEITE, 1890, p. 170-171, grifo nosso).

\subsection{Leis Gerais}

As leis gerais eram aquelas promulgadas para vigorar na metrópole, dentro do território de Portugal, mas tinham a sua eficácia estendida também aos territórios das colônias, sendo publicadas nas vilas pelas Câmaras.

Devido à condição de existência diferente das colônias (social, moral, econômica), as leis metropolitanas em grande parte não eram adaptáveis ao Brasil.

Mesmo em tempos mais adiantados, muitas das leis da metrópole permaneceram inaplicáveis, em razão das situações jurídicas não corresponderem; por outro lado, da mesma forma algumas situações jurídicas das colônias ficariam sem regulamentação, por falta de previsão na legislação geral portuguesa.

Portanto, as leis da metrópole não conseguiam prever, ainda que fosse de maneira geral, a organização das diversas colônias.

Era, assim, difícil determinar um critério para distinguir as leis gerais aplicáveis, ou não, às colônias, de forma que era necessário dar publicidade aquelas que teriam aplicação, por meio de divulgação nas Câmaras das Vilas.

Nesse aspecto, grande era a dificuldade de publicação das leis no Brasil uma vez que os métodos tradicionais, muitas vezes, não resultavam eficazes, tais como a fixação de editais, divulgação de cópias, certidões e traslados, considerando ainda que muitos da população não sabiam ler, o que levava ao apregoamento público como a maneira mais efetiva de publicidade. ${ }^{1}$

\subsubsection{Direito comum português}

No período de formação do Estado português, ${ }^{2}$ o costume era a fonte primordial do direito, existindo costumes gerais e jurisprudenciais.

Mario Júlio de Almeida Costa explica que,

nessa época, utilizava-se o conceito de costume num sentido amplo ou residual: abrange todas as fontes de direito tradicionais que não tenham caráter legislativo. Denominação genérica em que se incluíam sentenças da

Sobre a aplicação das leis, ver Martim de Albuquerque (2002, v. 3, p. 97 e ss.) e José Justino de Andrade e Silva (1854. p. 312).

2 A respeito da formação do Estado Português ver, por todos, Marcello Caetano (1981, p. 177 e ss.). 
Cúria Régia, depois designadas costumes da Corte, de juízes municipais e de juízes arbitrais (juízes "alvidros” ou "alvedrios"), isto é, nomeados por acordo entre as partes, cujas decisões se tornavam precedentes vinculativos. (COSTA, 1996, p. 190 e ss.).

A partir do reinado de Afonso III, as leis gerais passam a ter supremacia sobre os costumes, como reforço da autoridade régia - influência do direito justinianeu - deixando de ser uma fonte esporádica e passando a ser modo corrente de criação do direito. (COSTA, 1996, p. 254 e ss.).

Portanto, após o século XIII se inicia um processo de individualização do direito, com o incremento das leis gerais, sob inspiração romano-canônica, como forma de reforço da autoridade régia, dando origem a fontes tipicamente portuguesas.

Tendo em vista a grande produção legislativa, como produto da vontade geral do soberano, e a necessidade de afirmação nacional, para apagar o poderio local dos senhores feudal (especialmente o pluralismo dos forais), teve início o processo de sistematização das normas existentes em Portugal. ${ }^{3}$

As Ordenações do Reino de Portugal representaram o esforço pioneiro dos monarcas na sistematização de normas, o que se deu a partir do reinado de D. João I, resultando na primeira das Ordenações, as Afonsinas, concluída e promulgada em 1446, sob o reinado de Afonso $\mathrm{V}$.

Destaque-se a grande importância desta primeira obra de sistematização do direito português, de índole oficial, que representa a síntese de todo o trajeto do direito em Portugal, desde a fundação da sua nacionalidade - com a autonomia do direito português.

As Ordenações Afonsinas deram o suporte para a evolução subsequente do direito português, sendo as demais ordenações - Manuelinas (1521) e Filipinas (1603) um trabalho de atualização.

Portanto, compreende-se como "direito comum português" o direito produzido e aplicado em Portugal, representado especialmente pelas Ordenações - Afonsinas, Manuelinas e Filipinas - e demais legislações extravagantes, como complemento às Ordenações, e que tinham a sua aplicação estendida, na medida do possível, às colônias de Portugal.

3 A respeito dos motivos que levaram a realização das Ordenações, ver Mário Júlio de Almeida Costa (1968, v. 44, p. 259 e ss.); Ignácio Maria Poveda Velasco (1994, v. 89). 


\subsection{Leis Especiais}

As leis especiais eram aquelas decretadas para vigorar única e exclusivamente dentro do território da colônia, eram, assim, distintas das disposições e normas da legislação geral metropolitana, tratando-se de disposições e normas particulares.

Inicialmente foi a espécie de lei que preponderou no Brasil, notadamente no período do sistema das Capitanias Hereditárias, tendo em vista as condições diferenciadas da colônia, o que dificultava a aplicação das leis gerais.

As leis especiais tinham a sua eficácia limitada, restrita aos limites do território da colônia, ao contrário das leis gerais, que tinham aplicação ampla, não apenas na metrópole, mas também fora, estendidas para as colônias.

A competência legislativa para a elaboração dessas leis especiais era igualmente da metrópole - com algumas exceções que autorizariam uma produção legislativa local - e representavam, portanto, o denominado direito colonial português.

\subsubsection{Direito colonial português}

Como espécie do gênero leis especiais, enquadra-se o direito colonial português, que compreendia uma elaboração legislativa visando a atender as condições particulares da colônia, devido a menor complexidade do regimento e organização.

Nessa espécie, incluem-se: (a) as leis do reino reformadas para a aplicação nas colônias; e, (b) as leis originariamente criadas para a(s) colônia(s).

$\mathrm{Na}$ primeira hipótese, o legislador português reformava as leis gerais, adaptando-as às condições particulares da colônia, moldando-as às instituições e órgãos da administração colonial; como exemplo, a instituição da administração municipal nas capitanias, com os concelhos, os juízes, etc., todos contando com regimentos próprios.

No tocante as leis originariamente criadas para as colônias, a metrópole produzia leis privativas, específicas para disciplinar os diversos aspectos da vida colonial. Essas leis eram criadas naquelas situações em que as leis gerais não regulavam a matéria, ou eram inaplicáveis na sua totalidade, ainda que fossem reformadas.

A título de exemplificação da necessidade dessa espécie de lei especial, citase a questão dos índios, dos escravos, das minas de ouro, cujas matérias eram exclusivas das situações e condições das colônias, e muitas vezes, apenas de algumas colônias.

Portanto, essas leis especiais, que tratavam da organização social, administrativa, judiciária, fiscal, militar e econômica da colônia, fruto da adaptação das normas existentes na metrópole, ou de criação legislativa em se tratando de matérias novas, compõe o denominado direito colonial português, posto que, não obstante fosse o expoente das condições da colônia, eram decretadas pelo poder metropolitano. 


\subsubsection{Legislação eclesiástica}

Até 1531 Portugal não enviou para o Brasil autoridade investida de poderes necessários para organizar os seus domínios, de forma que os primeiros atos legislativos que tiverem aplicação na colônia foram provenientes da Igreja.

A primeira legislação eclesiástica relativa ao Brasil foi a Bula de 24 de janeiro de 1506, do Papa Júlio II, confirmando a D. Manuel os direitos sobre as terras do Brasil em consequência do Tratado de Tordesilhas, e a Bula de 7 de junho de 1514, do Papa Leão X, confirmada em 1551 pela Bula do Papa Júlio III, unindo perpetuamente o Brasil à Coroa e domínio dos reis de Portugal.

Da mesma forma se deu no tocante a recepção das resoluções tridentinas pelos prelados do Reino de Portugal e Ultramar, como informa Marcello Caetano, ao dispor que foram expedidas cartas régias nesse sentido,

\section{(....) enviando-lhes o volume impresso em Lisboa com a bula e os decretos e a determinar-lhes que fizessem a respectiva publicação solene, pedindo a ajuda da justiça secular para a execução, quando necessária (...). (CAETANO, 1965, p. $10)$.}

Um pouco mais tarde, as Constituições Primeiras do Arcebispado da Bahia, geradas a partir do sínodo de 1707, iniciativa do arcebispo Monteiro e Vide, elaboradas como um intento de atualização da Igreja às condições do Brasil, dentre as quais a presença da escravidão, situação não contemplada na legislação canônica.

\subsection{Direito local}

Os forais e regimentos autorizavam os Capitães e Governadores a decretarem as disposições necessárias - dentro de limites fixados - para o complemento das leis emanadas da metrópole.

Essas leis, emanadas no próprio Brasil, eram consideradas como sendo fonte do direito local, e foram largamente utilizadas notadamente no período inicial da colonização, em que a presença da Coroa, por meio de seus representantes diretos, não era tão efetiva.

Por essa razão, no período do sistema das Capitanias Hereditárias, em que predominou a organização administrativa municipal, como será descrito no capítulo 4, infra, houve um grande número de leis emanadas das Câmaras das Vilas e Cidades, denominadas de Posturas.

Essa elaboração legislativa era autorizada pela metrópole, mas dentro de limites fixados nos forais e regimentos, de maneira de que não poderiam contrariar às leis do Reino. 
Ressalte-se o caráter originário dessa fonte, uma vez que se tratava de legislação emanada na própria colônia, decretada pelos governadores e pelas Câmaras, para prover necessidades peculiares locais ou municipais.

\section{Período das Capitanias Hereditárias}

\subsection{Sistema político-administrativo}

Ao tempo de D. João III, instala-se no Brasil o primeiro sistema políticoadministrativo, que se tornou conhecido como o das Capitanias Hereditárias (inalienáveis), doadas pelo Rei a fidalgos portugueses, e que perdurou por um período de 14 (quatorze) anos.

Referido sistema traduzia a tentativa de distribuir o encargo da colonização entre pessoas da confiança real, adotando-se modelo já utilizado nos Açores e na ilha da Madeira; e assim se procedia em caráter emergencial, dado o interesse de rivais estrangeiros nas terras descobertas.

D. João III distribuiu as terras do Brasil por 12 donatários, por meio das Cartas de Doação e dos Forais (1533/1535), diplomas esses que formavam o estatuto da capitania:

- as cartas de doação estabeleciam a legitimidade da posse de determinada porção de território colonial, envolvendo os direitos e privilégios dos donatários;

- os forais (determinações Reais), complemento às cartas de doação, estabeleciam os direitos, foros, tributos, etc., devidos ao rei e ao capitão-e-governador (donatários), a serem pagos pelos habitantes do seu território;

O sistema adotado consistia, basicamente, em um regime de caráter feudal, visto que os diplomas em questão davam quase completa soberania aos capitãesgovernadores em suas circunscrições territoriais, tornando-os senhores das terras e detentores do poder de distribuir e aplicar justiça, salvo com relação àquelas atribuições específicas, não concedidas ou delegadas pela Coroa; ou, ainda, naquilo que não fora apreciado nas cartas, e que deveriam reger-se pelas Ordenações e leis gerais do reino de Portugal.

Os donatários recebiam com as Capitanias os títulos de Capitão e Governador e o direito de fundar vilas, concedendo-lhes foros especiais e nomeando governadores, ouvidores, meirinhos, etc., mercê da lei vigente, que eram ao tempo as Ordenações Manuelinas, para as quais haviam se transplantado as normas das Afonsinas a respeito da organização administrativa e política das vilas e cidades (não variaram muito nas Ordenações Filipinas), abaixo descrita.

Nas capitanias brasileiras, que haveriam de moldar-se na organização política e administrativa da metrópole, teriam as câmaras que se formar e entrar em 
funcionamento (seriam, durante muito tempo, as únicas células do organismo político das capitanias): as capitanias, na verdade, eram mera expressão territorial, sem governo próprio, que tão logo não se instalaria, por força das circunstâncias.

O governo das capitanias se contraia nos governos das vilas: os capitães eram muito mais alcaides mores das vilas do que da própria capitania: se territorialmente elas se alargavam pelo sertão adentro, administrativamente minguavam na vida das vilas que se erguiam timidamente nas costas marítimas.

A população das vilas se constituía, basicamente, de fidalgos (a maior parte dos sesmeiros), peões (colonos e os criminosos ou degradados, vindos de Portugal), e os gentios (índios, escravizados, negros africanos).

Cada vila tinha a sua casa de Câmara (organização primitiva: escrivão (funcionava também como Tabelião Judicial e Notas); escrivão de órfão e juiz pedâneo), à qual competia o governo municipal, a administração do Concelho, (todos eleitos pelos vizinhos e independentes do poder régio), que tinham também atribuições legislativas e judiciárias, composta de:

a) Juízes ordinários - eleitos pelos vizinhos do Concêlho, entre os homens bons, cujas listas eram previamente apuradas e sua nomeação era confirmada pelo Capitão ou por seu ouvidor; sua competência era restrita, dentro dos limites da vila, só no cível e em ações novas. Contra suas decisões era admitido recurso para o Ouvidor da capitania.

b) Vereadores.

c) Procurador do Concêlho.

As Ordenações Filipinas (assim como também as Manuelinas), no Livro I, Título LXVI, dispunha a respeito das atribuições dos Vereadores, abaixo descritas:

Dos Vereadores

Aos Vereadores pertence ter carrego de todo o regimento da terra e das obras do Concelho, e de tudo o que puderem saber, e entender, porque a terra e os moradores della possam bem viver, e nisto hão de trabalhar [...]

E todos os Vereadores irão à Vereação à quarta-feira e ao sabbado, e não se escusarão sem justa causa. E o que não for, pagará por cada hum dia, cem réis para as obras do Concelho os quaes logo o Scrivão carregará em receita sobre o Procurador, sob pena de os pagar noveados... [...].

Anexo às Câmaras funcionavam os almotacés, incumbidos da limpeza e polícia econômica dentro da cidade ou vila, o almoxarife ou funcionário incumbido do exercício dos direitos e privilégios da Coroa (cobrança dos dízimos e demais tributos 
devidos conforma cartas de doação e forais), e o alcaide - encarregado da defesa militar das vilas. ${ }^{4}$

\subsection{Legislação}

\subsubsection{Leis gerais}

Tendo em vista as condições da colônia nesse período, que se encontrava em uma fase inicial de desenvolvimento, as leis gerais tiveram muito pouca aplicação, especialmente no que se refere às Ordenações Afonsinas.

Ademais, como exposto acima, preponderava a forma de administração local, em que prevaleciam os interesses locais, regulados por meio das leis emanadas das Câmaras.

\subsubsection{Leis especiais}

Prevaleceram nesse período as leis especiais, adaptando ou moldando as leis gerais para as condições peculiares da colônia, ou produzidas especialmente para a mesma.

Como primeiras manifestações de leis especiais, inserem-se as cartas de doação e os forais, documentos esses que formalizavam a doação das capitanias.

Nas cartas de doação constavam a natureza e a extensão dos direitos que cabiam aos capitães e donatários, e nos forais, disposições relativas às concessões de terras em sesmarias, regulamentação do comércio, reservas dos direitos e privilégios fiscais da Coroa.

\subsubsection{Direito local e costumes}

Destacam-se também as leis emanadas nas Cidades e nas Vilas, fontes do direito local, tendo em vista, como se disse, a predominância da forma de organização administrativa municipal, como complemento das leis da metrópole.

\footnotetext{
$4 \quad$ A respeito do poder e autonomia das elites municipais no Brasil durante o período colonial ver por todos Raimundo Faoro e Charles Boxer, que divergem a respeito do grau de atuação dos senados municipais em relação ao controle e autoridade da Metrópole. (BOXER, 2002) e (FAORO, 1976).
} 


\section{Período do Governo-Geral}

\subsection{Sistema político-administrativo}

A ausência de fiscalização da Coroa e os amplos poderes conferidos aos capitães levaram à ocorrência de excessos e abusos: os cargos públicos normalmente eram ocupados por degredados ou por pessoas desprovidas de qualquer preparo para o atendimento dessas funções.

Em 1548, em razão do fracasso do sistema das capitanias, a grande maioria abandonada, com exceção de S. Vicente e Pernambuco - D. João III resolve adotar um sistema centralizado de administração da colônia - enviando delegados imediatos da Coroa, os Governadores-Gerais, ${ }^{5}$ incumbidos de amplas funções executivas e o ouvidorgeral, com atribuições judiciárias. Regulavam-nas os Regimentos do Governo-Geral. ${ }^{6}$

Por meio da Carta Régia de 7 de janeiro de 1549, foi delegado a autoridade do governo do Brasil e um governador-geral, com sede na Bahia, representante direto do governo metropolitano.

Inalterada a divisão do território em Capitanias: à testa desta ficaram os respectivos capitães-mores, quer donatários, quer de nomeação governamental;

Subsistem os órgãos da administração das vilas e povoações - os Concêlhos com as respectivas Câmaras, os Capitães de vila e os Alcaides.

Desta forma, embora mantido o sistema de capitanias, foi-lhe sobreposto outro sistema, de controle, exercido pelo rei. Assim, na estrutura judicial existente introduziu-se a figura do ouvidor-geral, como uma extensão do poder da coroa, elemento intermediário entre os ouvidores e a Casa da Suplicação, em Lisboa.

\subsection{Legislação}

\subsubsection{Leis gerais}

Tendo em vista a instituição de um novo sistema administrativo centralizador, com representantes diretos do governo metropolitano, passa a predominar um governo com direção única, o que leva a redução da autoridade da administração local, com a predominância, no campo legislativo, das leis gerais e especiais, abaixo tratadas.

$\mathrm{O} 1^{\circ}$ regimento foi entregue a Thomé de Souza, com sede na Bahia.

6 Os regimentos eram determinações reais especiais, em matéria de direito público e administrativo, assim como os alvarás, cartas régias, para adequar a legislação portuguesa à nossa organização administrativa. O mesmo não ocorria com relação ao direito privado, que era a transferência da legislação portuguesa, quase sem alterações: as Ordenações do Reino - Afonsinas (1446), Manuelinas (1521) e posteriormente, as Filipinas (1603), que mais tempo vigoraram no Brasil, até a promulgação do Código Civil brasileiro, em 1916. 
Por outro lado, além do aspecto da maior presença da Coroa no Brasil, um aumento da complexidade da vida na colônia possibilita uma maior aplicação do direito comum português, em detrimento, gradativamente, a aplicação dos direitos locais e costumeiros que predominavam no período anterior.

Portanto, enquadrado como legislação geral, passou a ter aplicação no Brasil, na medida do possível, a Coleção de D. Duarte - obra de índole privada, de meados do séc. XV, anterior às Ordenações - as Ordenações Manuelinas (1521) e posteriormente as Ordenações Filipinas (1603), bem como os Cânones do Concílio de Trento (1563) e a Concordata de 1578 (ampliando a jurisdição do Clero sobre bens e rendas da Igreja).

\subsubsection{Leis especiais}

Considerando a maior complexidade da vida colonial, o aumento da população, desenvolvimento da agricultura, indústria, se fazia necessária a reforma das Instituições existentes, bem como a criação de novas, dando funcionários e atribuições.

Essa produção legislativa para a formação do novo regime - do GovernoGeral - foi feita por meio (a) dos Regimentos, que regulavam matérias referentes à organização administrativa (Regimento do Governador-Geral, do Ouvidor-Geral, etc.); (b) dos Alvarás ou Cartas Régias, para as demais matérias, para dar instruções aos funcionários.

Ademais, também foi produzida legislação a respeito dos índios e escravos, bem como uma legislação eclesiástica, criando um bispado no Brasil, com sede na Bahia (Bula de 25/02/1551), tendo em vista que não havia, até então, um representante direto da Igreja no Brasil, apenas os padres Jesuítas.

\section{Organização judiciária}

A justiça colonial portuguesa compreendia, dentro da sua estrutura formal, elementos que representavam o esforço centralizador da autoridade real.

Desta forma, a justiça colonial portuguesa compreendia uma justiça real diretamente exercida, de caráter originário e especializada, e uma justiça concedida por delegação real.

A primeira espécie de justiça, como se disse acima, de caráter ordinário e especializado, era composta pelos Ouvidores (Gerais e das Capitanias), os Desembargadores (dos Tribunais de Relação), bem como pelos Juízes de Fora e outros juízes especiais.

Por sua vez, a justiça concedida por delegação real era aquela jurisdição atribuída aos donatários, definida nos Forais e Cartas de Doação, tanto para a justiça cível como criminal, atribuindo-lhes competência para nomeação de ouvidores particulares, juízes ordinários, escrivães e outros oficiais. 
Destaque-se que no período das Capitanias Hereditárias preponderava a justiça concedida por delegação, consubstanciada no poder local, ou municipal (das Câmaras), em razão da menor presença do poder Real.

A justiça municipal era exercida pelos juízes ordinários, cujas atribuições encontravam-se definidas nas Ordenações do Reino, e cuidavam do julgamento de questões de menor monta (Ord. Manuelinas, Livro I, Tít. 44; Ord. Filipinas, Livro I, Tít. $65)$.

A partir da instituição do sistema do Governo-Geral, em que a presença do poder real se tornou mais marcante, passa a prevalecer a justiça real diretamente exercida, por meio de representantes diretos da Coroa, destacando-se a figura do juiz de fora, que fazia cessar a jurisdição do juiz ordinário quando se encontrava presente na localidade.

O juiz de fora fazia parte da justiça profissional, ou especializada, pois se tratava de juiz letrado, versado nas leis portuguesas, cujas atribuições também se encontravam definidas nas Ordenações Filipinas, Livro I, Título LXV, sendo magistrados de nomeação real:
Dos Juízes ordinários, e de fora
Os Juízes ordinários e outros, que Nós de fora mandarmos, devem trabalhar, que nos lugares e seus termos, onde forem juízes, se não façam malefícios, nem malfeitorias. $\mathrm{E}$ fazendo-se, provejam nisso, e procedam contra os culpados com diligencia.
E, os Juizes ordinários trarão varas vermelhas, e os Juizes de fora brancas continuadamente, quando pela villa andarem, sob pena de quinhentos réis por cada vez, que sem Ella foram achados.
E porque os Juizes ordinários com os homens bons têm o Regimento da cidade, ou villa, elles ambos, quando poderem, ou ao menos hum, irão sempre à vereação da Camera, quando se fizer para com os outros ordenarem o que entenderem, que He bem commum, direito e justiça.
E onde não houver Juízes dos Orphãos, os ordinários guardarão e cumprirão em todo o Regimento, que specialmente He dado ao Juiz dos Orphãos.

No Brasil, os juízes de fora foram efetivamente estabelecidos a partir de fins do séc. XVII, com o objetivo de corrigir a ação dos juízes ordinários, sendo encarregados da correta aplicação da justiça do Reino e para aumentar o poder do monarca.

Como explica Candido Mendes de Almeida,

Juiz de fora ou de fora-aparte, como a princípio se denominaram desde o primeiro instituidor, o rei D. Afonso IV, era o magistrado imposto pelo rei a qualquer lugar, 
sob o pretexto de que administravam melhor a justiça aos povos do que os juízes ordinários ou do lugar, em razão de suas afeições e ódios. (...) O juiz de fora era de ordinário letrado, ou antes instruído no direito romano, legislação mui patrocinada pelo príncipes, pelo predomínio que lhes asseguravam no Estado; ao revés do juiz ordinário, que administrava justiça aos povos tendo em vista o direito costumeiro, os forais, que não podião ser do agrado do Poder Real, e nem dos Juristas Romanos a seu soldo. O Juiz Ordinário era um Juiz independente da Realeza, e a legislação que executava estava fora dão alcance do mesmo poder, e só o costume poderia altera-la. (...) (Ordenações Filipinas, Livro I, Título LXV, p. 134).

Ainda dentre os juízes especiais, havia os juízes de órfãos e o juiz das vintenas ou pedâneo, cujas atribuições encontram-se descritas nas Ordenações, atuavam no Termo, podendo ser substituídos, na ausência, pelos Juízes Ordinários.

O Juiz das vintenas ou pedâneo era um juiz eminentemente popular, que levava a justiça às aldeias que tivessem de 20 (vinte) vizinhos para cima, escolhido dentre os homens bons, e sua jurisdição limitava-se à causas de mínima importância, com o intuito de dar uma pronta solução aos litígios, ${ }^{7}$ como descrito nas Ordenações Filipinas, Livro I, Título LXV:

Juízes das vintenas

73. Mandamos, que em qualquer aldeã, em que houver vinte visinhos, e d'ahi para cima até cincoenta, e for uma legoa afastada, ou mais da cidade, ou villa, de cujo termo for, os juízes da dita cidade, ou villa, com os Vereadores e Procurador, escolham em cada hum anno hum homem bom da dita aldeã, que seja nela Juiz; ao qual darão juramento em Camera, que bem e verdadeiramente conheça e determine verbalmente as contendas, que forem entre os moradores da dita aldeã, de quantia até cem réis. E sendo a aldeã de cincoenta visinhos até cento, conhecerá de quantia de duzentos réis. [...].

Com relação aos Juízes de órfãos, deveriam ser pessoas com mais de 30 (trinta) anos, designados para vilas e lugares que contassem no mínimo com 400 vizinhos, e tinham como atribuição o julgamento de causas que envolvessem interesses de órfãos, ausentes, escravos, irmandades, associações religiosas, etc.., nos termos das Ordenações Filipinas, Livro I, Título LXXXVIII:

Dos Juízes dos Orfãos

Ver, a respeito, Waldemar Martins Ferreira (1951, t. 1, p. 111-114). 
Antigamente o prover sobre as pessoas e fazendas dos Órfãos pertencia aos Juizes ordinários e Tabelliães, e por suas ocupações serem muitas, e não poderem cumprir com esta obrigação, como deviam, foram ordenados os Officios de Juiz e Scrivão dos Orfãos, para specialmente proverem nas pessoas e fazendas deles, no que devem ter grande cuidado, pola muita confiança, que nelles he posta. E em todas as villas e lugares, onde nelles e no termo houver quatrocentos visinhos, ou dahi para cima, mandamos que haja juiz dos Orfãos apartado (1) E onde não houver o dito numero de visinhos, os Juizes ordinarios sirvam o Officio de Juiz dos Orfãos com os Tabelliães da villa: salvo se nas villas e lugares, que a quatrocentos visinhos não chegarem, houver costume e posse antiga de haver Juiz dos Orfãos, ou forem per Nós ordenados. Os quaes Juizes ordinários serão obrigados cumprir e guardar em tudo o conteúdo neste titulo, sob as penas nelle declaradas.

E o que houver de ser Juiz dos Orfaõs, será de trinta anos (1), e dahi para cima. E servindo, não sendo da dita idade, ora a dada seja nossa, ora da Camera, ou de algum Senhor de terras, perca o Officio, e nunca mais o haja; e Nós o daremos a quem nossa mercê for; e mais perderá a metade de sua fazenda $[\ldots]$.

De acordo com Candido Mendes De Almeida, nos comentários ao título que trata dos Juízes de Órfãos nas Ordenações, esse juízo teria sido criado no Brasil por meio de Alvará, de 2 de maio de 1731, tendo em vista o maior crescimento da população, tendo-lhe sido atribuído um regimento especial.

No entanto, existem registros anteriores da existência desse juiz na cidade do Rio de Janeiro, nos regimentos do Ouvidor-Geral da repartição Sul e também em carta régia de $1694 .{ }^{8}$

Também fazia parte de todo esse aparato judiciário, diversos auxiliares: escrivães, tabeliães judiciais, meirinhos, etc.

Embora não considerado parte do aparato administrativo colonial, há de se incluir na estrutura a Casa da Suplicação de Lisboa - tribunal superior português, de $3^{\text {a }}$ e última instância - que exerceu grande influência no Brasil, tomado como modelo para os tribunais brasileiros superiores - posteriormente criados, servindo, ademais, como tribunal de apelação, examinando causas provenientes das colônias, até a instalação do primeiro Tribunal da Relação.

A esse respeito, ver Salgado Graça (1985). 
Finalmente, cumpre mencionar o órgão mais importante da estrutura judiciária portuguesa, o Desembargo do Paço - que em verdade não tinha função de tribunal, ${ }^{9}$ mas de assessoria para todos os assuntos de justiça e administração legal participando da organização judiciária colonial brasileira na medida em que indicava e fiscalizava os magistrados delegados da Coroa.

Foi somente em 1588 que se criou um tribunal de apelação no Brasil em razão do aumento do número de recursos das decisões dos ouvidores gerais, e da impossibilidade da metrópole atendê-los de maneira eficaz - denominado Relação do Estado do Brasil, ou Relação da Bahia, funcionou de 1609 até 1626, quando teve suspensas suas atividades, para ver-se restabelecido em 1652.

\subsection{Período das Capitanias Hereditárias}

Competia aos capitães-e-governadores a organização da justiça - de cujos poderes haviam sido investidos por meio das cartas de doação - com a nomeação de Ouvidor dentro de sua área de competência.

Este ouvidor era o representante judicial dos donatários, primeira autoridade da justiça colonial, subordinado ao capitão - nomeado pelo prazo renovável de 3 (três) anos, com competência em matérias cível e criminal, aqui resumidas nos seguintes termos:

a) Em primeira instância em um raio de até 10 léguas de distância de sua residência, e em $2^{\mathrm{a}}$ instância para examinar recursos das decisões dos juízes menos categorizados (magistrados municipais);

b) Tinha alçada nas causas cíveis que não ultrapassassem o valor de 100 mil réis e 100 cruzados de pena com relação aos fidalgos. Acima desses valores cabia, em tese, recurso à Casa da Suplicação, em Lisboa; ${ }^{10}$

c) Nas causas criminais, na hipótese de pena de morte, julgava conjuntamente com o donatário, sem possibilidade de recurso. Com relação aos fidalgos, a jurisdição do ouvidor era mais limitada, podendo sentenciá-los a pena de, no máximo, 10 anos de degredo, salvo em caso de crimes mais graves, tais como blasfêmia, heresia, sodomia e falsificação, aos quais aplicavam-se, também, a pena de morte, sem possibilidade de recurso.

Cabia, ainda, aos capitães e aos ouvidores, prover à eleição de juízes e oficiais dos Concelhos das Vilas, bem como aos cargos de tabeliães público e judicial.

\footnotetext{
9 Somente causas de mérito especial podiam ser levadas à apreciação deste órgão, que era um conselho governamental, presidido pelo Rei, tendo como incumbência, dentre outras, a fiscalização dos vários postos da magistratura.

10 Não se conhecem casos, nessa época, de recursos que chegaram a Lisboa.
} 
Os Concelhos das Vilas ou das Cidades era a base da estrutura judicial e administrativa, composto por funcionários administrativos e judiciários (vereadores, juízes ordinários, escrivães, homens bons (experientes: idade, cargos ocupados, situação econômica, etc.), que se reuniam em média 2 (duas) vezes por semana, e cuidavam dos interesses da vila ou cidade.

Nesse período das Capitanias Hereditárias, como esclarecido anteriormente, preponderava a justiça concedida por delegação, consubstanciada no poder local, ou municipal (das Câmaras), em razão da menor presença do poder Real, como muito bem traduz Padre Antonio Vieira, no Sermão da terceira dominga da Quaresma, abaixo transcrito:

\begin{abstract}
Nos Brasis, nas Angolas, nas Goas, nas Malacas, nos Macaus, onde o rei se conhece só por fama e se obedece só por nome; aí são necessários os criados de maior fé e os talentos de maiores virtude. Se em Portugal, se em Lisboa, onde os olhos do rei se vêem e os brados do rei se ouvem, faltam a sua obrigação homens de grandes obrigações, que será in regionem longiquam? Que será daquelas regiões remotíssimas onde o rei, onde as leis, onde a justiça, onde a verdade, onde a razão e onde até mesmo Deus parece estar longe? (VIEIRA, 1951, v. 3, p. 195).
\end{abstract}

A justiça municipal era exercida pelos juízes ordinários, cujas atribuições encontravam-se definidas nas Ordenações do Reino, e cuidavam do julgamento de questões de menor monta. (Ord. Manuelinas, Livro I, Tít. 44; Ord. Filipinas, Livro I, Tít. $65)$.

O cargo de juiz ordinário era ocupado por pessoas leigas, sem formação jurídica, os quais eram eleitos anualmente pelos homens bons da comunidade, normalmente em número de 2 (dois), que se reuniam em duas audiências semanais, nas localidades com mais de 60 habitantes, ou uma, se menor (nas pequenas vilas nem a audiência semanal era viável, às vezes a audiência era mensal).

Os processos eram instruídos e julgados na casa de vereação, e era aplicado na maior parte das vezes o direito local, em detrimento do direito português que, como se disse, representava os interesses da Coroa.

Nesse sentido, como exposto no item 6, supra, a própria legislação reinol, consubstanciada nas Ordenações, atribuía essa competência aos juízes ordinários, que tinham autonomia para aplicação da legislação local e dos costumes, considerando as dificuldades, nesse período inicial da colonização, de fazer prevalecer a legislação oficial em tão vasto território da colônia. (WEHLING; WEHLING, 2004).

Apesar de constar a figura do juiz de órfãos na legislação reinol, como parte integrante da estrutura judicial, a data da sua criação no Brasil é controversa, como 
exposto no item 6, supra. Com relação ao juiz das vintenas, como um juiz eminentemente popular, era nomeado para aquelas aldeias que tivessem mais de 20 (vinte) vizinhos, com jurisdição limitada à causas de mínima importância.

A estrutura da organização judiciária nesse período pode ser descrita na forma consignada no organograma abaixo, onde se pode verificar que o ouvidor era a figura principal do sistema, tendo em vista que ainda não existia um Tribunal de $2^{\mathrm{a}}$ instância constituído no Brasil.

\section{Ouvidor Particular}

Juiz de Órfãos
Juiz Ordinário

Juiz das Vintenas

ou Pedâneo

Cortes de Segunda e Terceira Instâncias

Cortes de Primeira Instância

\subsection{Período do Governo-Geral}

A organização da justiça Colonial brasileira passa cada vez mais a refletir a estrutura judicial portuguesa, com a expansão do quadro de funcionários e autoridades: o período correspondente ao final do século XVII e início do século XVIII reflete as mudanças em decorrência de uma maior autoridade régia no ultramar, fruto da política pombalina, com práticas centralizadoras, sendo estabelecidos no Brasil novos órgãos e agentes do governo central, dentre os quais o ouvidor-geral, e a disseminação do juiz de fora, juiz de carreira indicado pela Coroa, que passará a presidir as Câmaras e assegurar a aplicação da legislação reinol.

A figura principal do organismo judiciário passa a ser o ouvidor-geral nomeado por um período de 3 (três) anos - que deveria zelar pela observância das leis do reino e proceder de acordo com seu regimento próprio, incumbindo ao governador-geral fazê-lo cumprir seu encargo, bem como fiscalizar a jurisdição dos capitães - delimitada nas cartas de doação e forais - e seus eventuais excessos. 
No topo da hierarquia, encontramos a figura do Ouvidor-Geral, ${ }^{11}$ que concentrava atribuições judiciárias em $1^{\mathrm{a}}$ instância e em grau de recurso, e que se sobrepõe a estrutura anterior:

Em primeira instância julgava, nos casos crimes, com possibilidade de recurso à Casa da Suplicação, em Lisboa. Na hipótese de pena de morte, devia julgar com o governador, sem recurso, sendo ambos conformes nos votos. No caso de discordância, os autos eram remetidos ao corregedor da Corte. Em se tratando de pessoas de melhor qualidade, tinham alçada até 5 anos de degredo, sem apelação. No cível, tinham alçada até 60 mil réis, sem apelação nem agravo - acima desse valor, cabia recurso à Corte;

Em $2^{\mathrm{a}}$ instância, presidia audiência dos recursos das sentenças proferidas pelos ouvidores de comarca;

O ouvidor-geral exercia, cumulativamente, as funções de corregedor da Corte, inspecionando a situação da justiça nas capitanias - e quando em correição, mantinha jurisdição, nos limites da sua alçada, até 15 léguas ao seu redor - e de Chanceler da Corte, proferindo sentença em nome de El-Rei, assinando-as e selando-as com os selos das armas reais.

Ainda na mesma estrutura, logo abaixo do ouvidor-geral, em $1^{\circ}$ grau de jurisdição, seguiam-se outros componentes da hierarquia judiciária, cujas atribuições encontram-se já descritas nos itens 6 e 6.1, supra, abaixo enumerados: ${ }^{12}$

a) Juizes singulares:

- ouvidores de comarca;

- juizes ordinários;

b) Juizes especiais:

- juizes de fora;

- juizes de órfãos;

- juiz das vintenas ou pedâneo.

Existia a possibilidade de envio de recursos para a Casa da Suplicação de Lisboa - Tribunal Superior Português de $3^{\mathrm{a}}$ e última instância - como Tribunal de Apelação, até a instalação do primeiro Tribunal da Relação no Brasil, ainda durante o sistema do Governo-Geral.

Como se disse anteriormente, em 1588 foi criado um tribunal de apelação no Brasil - em razão do aumento do número de recursos das decisões dos ouvidores

11 As suas atribuições são imprecisas, pois não dispomos de nenhuma cópia de seu regimento, razão pela qual citamos algumas, em termos gerais.

12 As atribuições dos ouvidores e juízes se encontram descritas nas Ordenações Filipinas, Livro I, Título LXV e seguintes, transcritas no item 6 e 6.1 , supra. 
gerais, e da impossibilidade da metrópole atendê-los de maneira eficaz - denominado Relação do Estado do Brasil, ou Relação da Bahia, que funcionou de 1609 até 1626, quando teve suspensas suas atividades, para ver-se restabelecido em 1652.

Em 13 de outubro de 1751 foi criado um segundo tribunal do Brasil, a Relação do Rio de Janeiro, por meio de Alvará, considerando a necessidade de resolver problemas de morosidade no julgamento dos recursos, constituído nos mesmos moldes do Tribunal da Bahia. (WEHLING; WEHLING, 2004).

Em tais condições, assim se estruturou a organização judicial da colônia, a partir dessas modificações:

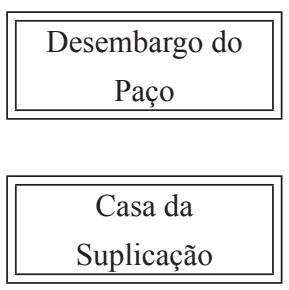

$\underline{\text { Brasil }}$

\begin{tabular}{|c|}
\hline Tribunal da \\
Relação
\end{tabular}

Ouvidor-Geral

Ouvidor

Particular

\begin{tabular}{|l|}
\hline Juiz de \\
Órfãos \\
\hline
\end{tabular}

\begin{tabular}{|c|}
\hline Juiz \\
Ordinário \\
\hline
\end{tabular}

Juiz de

Fora

Juiz das
Vintenas
ou Pedâneo


A $2^{\text {a }}$ instância no Brasil foi introduzida nos moldes da Casa da Suplicação - na sua instalação definitiva, compunha-se de 8 (oito) membros, também denominados desembargadores, tendo o governador-geral como presidente. ${ }^{13}$

O Tribunal contava, em sua composição, com um chanceler, dois desembargadores do agravo e apelação, dois ouvidores gerais, um juiz e um procurador dos feitos da coroa e da fazenda e promotor de justiça, um provedor dos defuntos, ausentes e resíduos, dois Desembargadores extravagantes, além de outros funcionários menos importantes: secretários, médico, capelão, meirinho e um guarda-mor. ${ }^{14}$

O Chanceler era o magistrado de maior importância e grau: iniciava as sessões e tinha como atribuições registrar as leis e ordenações emanadas pelo governador, bem como rever as sentenças e decretos para assegurar-se de que não estavam em contradição com os estatutos já existentes. Sua competência abrangia ainda o exame das acusações contra o governador, bem como contra os outros magistrados do tribunal e vários funcionários menos categorizados. Na ausência do governador, respondia pelo governo (art. 16 do RI da Casa da Suplicação).

Os Desembargadores possuíam alçada para conhecer de todos os recursos de apelação crimes e também os cíveis excedentes da alçada dos outros julgadores. Quanto aos agravos, tinham jurisdição cível e crime em Salvador e todos os lugares que fossem de competência desta capitania: com relação às demais, julgavam os agravos cíveis de alçada excedente ao dos outros magistrados, até a soma de 2 mil réis em bens imóveis e a 3 mil réis em bens pessoais. Acima desses valores, os agravos deveriam ser encaminhados à Casa da Suplicação.

Os ouvidores gerais foram incorporados à nova estrutura judicial e passaram a presidir audiências cíveis por ação nova de todos os feitos da cidade de Salvador e dos lugares que fossem da jurisdição desta capitania, com alçada de até 15 mil réis em bens de raiz e 20 mil réis em bens móveis. Com relação às causas criminais, tinham competência para conhecer por ação nova de todos os feitos crimes em Salvador e nos lugares de jurisdição desta capitania, bem como julgar todos os agravos vindo de outras partes, que não fossem de competência de outro julgador.

O Juiz dos feitos da Coroa, Fazenda e Fisco julgava as causas de interesse da Coroa, em $1^{\mathrm{a}}$ instância em Salvador e em grau de recurso das outras capitanias, e o procurador - advogado e fiscal da Coroa - devia conhecer de todas as causas para requerer o que fosse a bem da justiça de El-Rei.

\footnotetext{
13 O governador-geral podia assistir às sessões do tribunal, mas não tinha direito a voto. Cabia-lhe também pagar os funcionários, nomear membros ad hoc, designar desembargadores para visitar outras capitanias, etc.

14 Recolhiam as multas fixadas pelo tribunal.
} 
Já o Provedor dos órfãos, defuntos e ausentes, cuidava de problemas de testamentos, sucessões, etc., conhecia por ação nova, em Salvador e na jurisdição desta capitania, das causas com alçada de 20 mil réis em bens móveis e 15 mil réis em bens de raiz.

Em casos excepcionais admitiam-se recursos à Casa da Suplicação, como terceiro grau de jurisdição, bem como ao Desembargo do Paço, ambas as instituições com sede em Lisboa. ${ }^{15}$

7. Modificações nos Pródromos da Independência (1808-1822)

7.1. A inversão brasileira

A invasão francesa na Península Ibérica leva a transferência da Corte portuguesa para o Brasil, dando início a sua autonomia jurídica e econômica, sendo gradativamente rompidas as amarras de Portugal, sendo aqui praticadas todas as funções que outrora eram realizadas no além-mar.

Como observa Emília Viotti da Costa, as medidas tomadas por D. João VI, objetivando dotar o Brasil de instituições para moldá-lo à nova condição de sede do governo, assim como a abertura dos portos a todas as nações em 1808, com a extinção do monopólio comercial, e a elevação, em 1815, à categoria de Reino Unido, acabaram por levar, mais tarde, a conclusão da impossibilidade de se manterem as duas Coroas, tendo em vista o gradativo processo de independência da colônia, especialmente no campo comercial. (COSTA, 1999, p. 38 e segs.)

Com a transferência da família real para o Brasil ocorre a chamada "inversão brasileira", passando a cidade do Rio de Janeiro a ser o centro irradiador da autoridade soberana direta, onde se confeccionavam as leis e se praticavam todos os atos de governo.

Para tanto, são criados novos Ministérios de Estado, bem como organizadas novas instituições políticas, administrativas, judiciárias, militares, transferidos arquivos governamentais, etc., o que revela uma grande atividade legislativa para possibilitar o exercício da alta administração na capital jurídica do Reino.

Nesse primeiro momento, a nova legislação emanada no Brasil tem um caráter acentuadamente público, tendo em vista a necessidade de organização de novas instituições, com a criação de serviços, cargos, etc., bem como não se mostra original, considerando que traduz todo o aparato administrativo e judiciário que outrora existia em Portugal.

15 A Casa da Suplicação era o tribunal superior do Reino, que inicialmente acompanhava a Corte e depois se fixou em Lisboa. 
Nesse mesmo sentido atesta Candido Mendes de Almeida, no seu prefácio ao Livro I das Ordenações Filipinas: (ALMEIDA, 1869, p. XXXV).

[...] Em 1807 a Côrte espavorida abandona as praias da Metrópole, e acolhe-se ao Brazil. Começava o anno de 1808.

Dessa epocha, que he memoravel nos fastos Brazileiros, proque he precursora da de sua independencia, até 1822; nenhum monumento de legislação assignala a estada da Dynastia Bragantina. Nenhum Codigo se fez, nem se projectou. Reinava em tudo o provisorio, com a incerteza, e a idéia da volta à Portugal.

Os Estadistas que nesse periodo figuravão, erão mediocres, e mui abaixo de sua missão, apenas se nota um oou outro reommendavel por sua literatura. A Realesa estava e vivia só, ninguem, pode-se dizer, auxiliava-a.

Excluamos a creação de altos Tribunaes, á guisa dos de Portugal; ornamentos indispensaveis à nova Côrte: nesse periodo em que tão grandes cousa podia rememorar a estada da Realesa Européia pela primiera vez na America, apenas se destão dous actos de alto interesse para o Brazil: o Decreto de 28 de janeiro de 1808 , e a Carta de Lei de 16 de Dezembro de 1815. O mais he secundario.

O primeiro datado da Bahia abre as portas do Brazil ao commercio estrangeiro, e deve-se aos conselhoe e perinacia de José da Silva Libôa, que morrêo Visconde de Cayrú. Por essa grande medida ficou o Brazil logo nessa parte equiparado á Metrópole, e em posição independente.

A segunda equiparou-nos completamente: não era já um Principado, titulo de uma Provincia da Metropole, era um Reino ligado pelo laço tão somente do Governo, mas ditincto dos outros. O Paiz, a antiga colonia assim organisada, era um corpo político, que facilmente se poderia destacar com todos os seus componetnets dos dous á que se achava concatenado. Daho á completa independência pouco distava. Apenas decorrido um lustro o facto consummoouse, como uma deducção logica [...]. (grifo nosso).

No campo do direito privado, cada vez mais predomina a aplicação das leis gerais, consubstanciada nas Ordenações Filipinas e legislação extravagante, em decorrência da maior complexidade das relações sociais e comerciais e considerando a crescente importância da administração central.

Não há ainda uma profusa elaboração legislativa que possa representar um direito próprio brasileiro, mas em muitos aspectos os atos legislativos aqui praticados 
atendiam os interesses do Brasil, rompendo com o Pacto Colonial e desagradando os interesses portugueses metropolitanos. ${ }^{16}$

Coroando o processo de emancipação do Brasil, o Decreto de 13 de maio de 1808, criando a Imprensa Régia na cidade do Rio de Janeiro, o que contribuirá para a pavimentação da nossa autonomia jurídica.

\subsection{As Instituições judiciárias.}

No campo da justiça, por meio do Alvará de 10 de maio de 1808 foi criada a Casa da Suplicação, nos moldes portugueses, tendo em vista a impossibilidade de se fazerem chegar os agravos e as apelações para a Casa da Suplicação de Lisboa, o que foi feito por meio da elevação do Tribunal da relação do Rio de Janeiro para a condição de supremo tribunal de justiça, nos seguintes termos:

$[\ldots]$

I - A Relação desta cidade se denominará Casa da Suplicação do Brasil, e será considerada como Superior Tribunal de Justiça para se findarem ali todos os pleitos em última instância, por maior que seja o seu valor, sem que das últimas sentenças proferidas em qualquer das Mesas da sobredita Casa se possa interpor outro recurso, que não seja o das Revistas, nos termos restritos do que se acha disposto nas Minhas Ordenações, Leis e mais Disposições. E terão os Ministros a mesma alçada que têm os da Casa da Suplicação de Lisboa. [...].

A origem desse importante Tribunal em Portugal decorre da atribuição inicialmente exercida pelo monarca, de interpretação autêntica da lei, o que o levava muitas vezes, a presidir às reuniões dos tribunais superiores, decidindo as questões que eventualmente surgissem.

Em virtude da complexidade cada vez maior da administração, o rei aos poucos vai deixando de presidir essas sessões dos tribunais, dando origem ao alvará de D. Manuel I, que confere essas funções à Casa da Suplicação. (COSTA, 1996, p. 296-297).

Referido alvará de 1518 conferia aos desembargadores da Casa da Suplicação a resolução de dúvidas de interpretação que surgissem a respeito de algum preceito e a dita solução ficaria registrada no Livro dos Assentos, tendo força vinculante para casos futuros idênticos, surgindo então esses assentos como jurisprudência obrigatória.

Candido Mendes de Almeida, no prefácio ao Auxiliar Jurídico (apêndice às Ordenações Filipinas) - que contêm a compilação de todos os Assentos da Casa da

16 Ver por todos Emília Viotti da Costa (1999, p. 37 e ss.). 
Suplicação, desde 1603 até a sua extinção no Brasil - informa que estes tinhão por fim fixar a verdadeira intelligência da Lei; e tomados na Meza Grande daquella Caza ou Relação tinhão, e ainda tem, força de lei. (ALMEIDA, 1869, v. 1, p. VI).

A solução adotada no alvará de 1518, conferindo à Casa da Suplicação essa atribuição, foi repetida nas demais Ordenações reinóis (Manuelinas e Filipinas):

por iniciativa de D. Manuel I, foram os poderes do Rei, nesse domínio, como que transferidos para o próprio tribunal supremo do Reino (Casa da Suplicação), mantendo o monarca, apenas, como da sua competência reservada, a interpretação daquelas dúvidas sobre cujo esclarecimento a Casa da Suplicação se mantivesse hesitante, e que o respectivo Regedor, por isso mesmo, entendesse devessem ser levadas à apreciação régia. (CRUZ, 1975, v. 14, p. 283).

Nesse sentido, dispunham as Ordenações Manuelinas, no Livro V, título LVIII, parágrafo $1^{\circ}$, a seguir transcrito:

quando os Desembargadores que forem no despacho de alguu feitos, todos ou alguu delles teurem algua duvida em algua nossa Ordenaçam do entendimento della, vam com a dita duvida ao Regedor, o qual na Mesa grande com os Desembargadores que lhe bem parecer determinará, e segundo o que hi for determinado se poerá a sentença. E se dita Mesa forem isso mesmo em duvida, que ao Regedor pareça que he bem de No-lo fazer, pêra Nós loguo deterinarmos, No-lo fará saber, pêra Nós nisso provermos. E os que em outra maneira interpretarem Nossas Ordenações, ou derem sentenças em algum feito, tendo algum delles duvida no entendimento da dita Ordenaçam, sem hirem ao Regedor como dito he, serm suspensos atee Nossa Mercê. E a determinaçam que sobre o entendimento da dita Ordenaçam se tomar, mandará o Regedor escrever no livrinho para depois nom viir em duvida.

Desta forma, quando surgiam dúvidas aos desembargadores daquele tribunal superior, em virtude do entendimento de algum preceito, seriam levadas ao Regedor, que convocaria os demais desembargadores e, juntos, fixavam a interpretação mais adequada, podendo inclusive, conforme o caso, submeter a dúvida à resolução do monarca, se subsistissem dificuldades interpretativas . (COSTA, 1968, p. 297).

As soluções fixadas eram registradas no Livro dos Assentos, passando a ter força vinculante para casos futuros, ou seja, tornavam-se jurisprudência obrigatória.

Essas mesmas disposições foram repetidas nas Ordenações Filipinas, no Livro I, título $\mathrm{V}$, parágrafo $5^{\circ}$, a seguir transcritas:

E havemos por bem, que quando os Desembargadores, que forem no despacho de algum feito, todos ou algum deles 
tiverem alguma dúvida em alguma nossa Ordenação do entendimento dela, vão com a dúvida ao Regedor; o qual na Mesa grande com os Desembargadores, que lhe bem parecer, a determinará e, segundo o que aí for determinado, se porá a sentença. E a determinação, que sobre o entendimento da dita Ordenação se tomar, mandará o Regedor escrever no livro da Relação, para depois não vir em dúvida. E se na dita Mesa forem isso mesmo em dúvida, que ao Regedor pareça, que é bem de no-lo fazer saber, para Nós logo determinarmos, no-lo fará saber, para nisso provermos, E os que em outra maneira interpretarem nossas Ordenações, ou derem sentença em algum feito, tendo algum deles dúvida no entendimento da Ordenação, sem ir ao Regedor, será suspenso até nossa mercê.

A Casa da Suplicação funcionava como um órgão legislativo, proferindo solução que passava a ter força normativa - assentos - e que eram proferidos em sessão especial, fixando a inteligência das leis e tendo por objetivo uniformizar o entendimento a respeito da interpretação in abstrato de uma regra constante das Ordenações.

Foram também transferidos para o Brasil o Desembargo do Paço, a Mesa de Consciência e Ordens, o Conselho da Fazenda, a Junta de Comércio, além de outras repartições instaladas por D. João VI, tudo para o pleno funcionamento do governo.

A Mesa do Desembargo do Paço e da Consciência foi criada por meio de Alvará de 22 de abril de 1808, reunindo aqui no Brasil os dois tribunais, que em Portugal eram instituições distintas, tendo por atribuição conhecer das causas de competência do Desembargo do Paço, do Conselho Ultramarino e da Mesa da Consciência e Ordens.

Também foi criado o Conselho Supremo Militar e de Justiça, por meio de Alvará de $1^{\circ}$ de abril de 1808 , no qual se reunia atribuições de diferentes órgãos de Portugal, com a função precípua de conhecer os negócios e crimes militares.

Nesse período foram criados mais dois tribunais da Relação, de São Luís do Maranhão, em 1812, e de Pernambuco, em 1821.

Como exposto no item 6 supra, a partir do século XVIII já estão disseminados os magistrados de nomeação régia, em detrimento dos juízes eletivos - com o propósito de aperfeiçoamento da justiça e para garantir a aplicação da legislação portuguesa.

Considerando o novo relevo do comércio no Brasil, foi instalado por meio de Alvará de 23 de agosto de 1808 a "Real Junta do Commercio, Agricultura, Fábricas, e Navegação deste Estado, e Domínios Ultramarinos", ou seja, um Tribunal do Comércio, tendo em sua alçada as questões referentes ao comércio terrestre, marítimo, agricultura, indústria e navegação.

Alguns juízos privativos foram transferidos para o Brasil, dentre os quais o dos feitos da Santa Casa da Misericórdia, que cuidava de todos os feitos que envolvessem a Santa Casa da Misericórdia, como autor ou réu, bem como o juiz conservador da 
nação inglesa, com atribuição de julgar os feitos em que estivessem envolvidos cidadãos britânicos. (ALMEIDA, 1869).

Finalmente, como se disse anteriormente no item 6.2, já a partir do século XVIII, em decorrência de uma maior autoridade régia no ultramar - fruto da política pombalina - disseminava-se a figura do juiz de fora, juiz de carreira indicado pela Coroa, que passava a presidir as Câmaras e assegurar a aplicação da legislação reinol.

Com a transferência da sede do governo para o Brasil, mais do que nunca se faz importante a presença desse magistrado letrado, indicado pela Coroa, sem vínculos com a população local, que visava assegurar a observância da legislação oficial, em contraposição aos julgamentos que eram feitos pelos juízes ordinários, que aplicavam um direito local e costumeiro, sendo mais suscetíveis de influência da elite municipal.

Nesse sentido, todas as decisões judiciais deveriam passar pela Chancelaria da Casa da Suplicação, com o fito de assegurar a aplicação da legislação oficial, tendo em vista a sua instalação no Brasil e de acordo com o que determinava o seu Regimento. (ALBUQUERQUE, 1982, p. 47-49).

\section{Análise crítica e considerações finais}

Como se viu, as especificidades do território brasileiro levaram a uma adequação do direito e da estrutura jurídico-administrativa portuguesa, do que decorreu, inicialmente, uma importância acentuada das Câmaras Municipais e do direito local, especialmente durante o sistema das Capitanias Hereditárias.

Essa condição da colônia concedeu uma esfera significativa de poder aos municípios, cuja autonomia estava intimamente ligada ao grau de ingerência da metrópole, por meio de seus órgãos oficiais, o que variou ao longo do período, de acordo com a conjuntura política e econômica.

A estrutura municipal refletia os interesses locais, em detrimento dos interesses da Coroa, com a aplicação do direito costumeiro, afastando-se das leis gerais, que representavam a aplicação do direito Português.

Para tanto, dentro da organização municipal, com autonomia para realizar julgamentos e para aplicar o direito costumeiro e o direito local, encontrava-se a figura do juiz ordinário, ou juiz da terra, que em conjunto com os vereadores constituíam os juízes de $1^{\circ}$ instância no Brasil.

A regulamentação dessa forma de administração municipal, como vimos, encontrava-se descrita nas Ordenações do reino - Manuelinas e Filipinas - que tiveram aplicação no Brasil, de forma que não se tratava do exercício de poderes arbitrários da elite local, mas reflexo da própria política da Metrópole, que atribuíram a particulares (terceiros) os encargos da colonização. 
Essa situação somente veio a se alterar com a crescente centralização do poder da Metrópole - refletido na administração, que se afasta dessa característica local - com a introdução de órgãos e representantes diretos da Coroa, do Governo Central, em detrimento da administração local, outrora realizada por um particular (capitão-donatário).

Assim, o aparato administrativo e judicial acompanhou essas transformações conjunturais - com uma preponderância maior, ou menor, da presença de autoridades representantes diretos da Coroa - que faziam prevalecer os interesses reais em prol dos interesses locais.

A alteração na condução das colônias portuguesas no além-mar especialmente em razão da descoberta do ouro na região de Minas Gerais no final do século XVII - levou a que fosse dada uma importância maior à administração da América, implicando assim, como se viu, em uma gradativa redução da autonomia da elite local e consequentemente a modificação de todo o aparato administrativo judicial.

Dentro desse contexto, passam a preponderar os juízes de fora - letrados e representantes diretos da Coroa - que presidem as Câmaras municipais, sem vínculos locais e aplicando a legislação geral portuguesa.

A reorganização político-administrativa da Colônia do Brasil reflete a centralização do poder da Coroa, com a observância da legislação oficial portuguesa, em detrimento dos interesses locais, representados pelo juiz ordinário, como se disse, que aplicava o direito costumeiro.

O controle e a ingerência do governo metropolitano foram se acentuando com o decorrer dos anos, o que se consolidou com a vinda da família real e da Corte portuguesa, cerceando a autonomia das elites locais, com um novo aparato judicial e administrativo e prevalecendo em definitivo as leis e determinações régias.

Como se viu, o processo de colonização do Brasil se deu pela transposição de uma estrutura social, cultural e política portuguesa - adaptada às nossas condições e realidade, especialmente considerando a grande extensão territorial.

Essa estrutura permanecerá, mesmo após a independência, até a elaboração da $1^{\text {a }}$ Constituição do Brasil de 1824, quando alguns órgãos serão suprimidos, outros alterados, mas tendo como espinha dorsal a organização judiciária com matriz europeia, herdada da nossa experiência colonial.

São Paulo, abril de 2018.

Referências

ALBUQUERQUE, Martim de. A aplicação das leis no ultramar durante o antigo regime. In: Estudos de cultura portuguesa. Lisboa: Imprensa Nacional - Casa da Moeda, 2002. v. 3. 
ALBUQUERQUE, Martim de. O regimento quatrocentista da Casa da Suplicação. Paris: Fundação Calouste Gulbenkian, 1982.

ALMEIDA, Candido Mendes de. Auxiliar jurídico - apêndice. In: Codigo Philippino ou Ordenações e Leis do Reino de Portugal: recopiladas por mandado D’El-Rey D. Philippe I. 14. ed. Rio de Janeiro: Typ. Instituto Philomathico, 1869. 2 v.

AZEVEDO, Luiz Carlos de; CARMIGNANI, Maria Cristina da Silva. A organização judiciária no Brasil Colônia. Revista UNIFIEO, Osasco, v. 2, n. 3, p. 35-42, 2000.

BOXER, Charles. R. O império marítimo português. Tradução Anna Olga de Barros Barreto. São Paulo: Companhia das Letras, 2002.

BRASIL. Constituições primeiras do arcebispado da Bahia feitas, e ordenadas pelo illustrissimo, e reverendissimo Senhor D. Sebastião Monteiro da Vide, $5^{\circ}$. arcebispo do dito arcebispado, e do Conselho de sua Magestade, propostas, e aceitas em o Synodo Diocesano, que o dito Senhor celebrou em 12 de junho do anno de 1707. São Paulo: Typographia 2 de Dezembro de Antonio Louzada Antunes, 1853.

CAETANO, Marcello. História do direito português. Lisboa: Editorial Verbo, 1981. v. 1: Fontes direito público (1140 1495).

. Recepção e execução dos decretos do Concílio de Trento em Portugal. Revista da Faculdade de Direito da Universidade de Lisboa, Lisboa, v. 19, p. 7-87, 1965. Separata.

COSTA, Emília Viotti da. Da monarquia à república: momentos decisivos. 7. ed. São Paulo: Fundação Editora da UNESP, 1999.

COSTA, Mário Júlio de Almeida. História do direito português. 3. ed. Coimbra: Almedina, 1996. . Temas de historia do direito: ordenações. Boletim da Faculdade de Direito da Universidade de Coimbra, Coimbra, v. 44, p. 259-270, 1968.

CRUZ, Guilherme Braga da. O direito subsidiário na história do direito português. Separata de: Revista Portuguesa de História, Coimbra, v. 14, 1975.

FAORO, Raymundo. Os donos do poder: formação do patronato político brasileiro. 3. ed. rev. Porto Alegre: Globo, 1976. 2 v.

FERREIRA, Waldemar Martins. História do direito brasileiro. Rio de Janeiro: Livraria Freitas Bastos, 1951/1952. Tomos 1 e 2.

HOLANDA, Sérgio Buarque de. Raízes do Brasil. 26. São Paulo: Companhia das Letras, 1995.

LEITE, Serafim. Monumenta Brasiliae. Roma: Monumenta Historica Societatis Iesu, 1890. v. 3. Disponível em: $<$ https://archive.org/details/monumentabrasili03leit $>$.

MARCOS, Rui Manuel de Figueiredo; MATHIAS, Carlos Fernando; NORONHA, Ibsen. História do direito brasileiro. 1. ed. Rio de Janeiro: Forense Universitária, 2014. 
PORTUGAL. Ordenações Filipinas. Reprodução da edição brasileira de Candido Mendes de Almeida. Rio de Janeiro: Typ. do Instituto Philomathico, 1870.

PORTUGAL. Ordenações Manuelinas. Coimbra: Real Imprensa da Universidade, 1797.

POVEDA VELASCO, Ignácio Maria. Ordenações do Reino de Portugal. Revista da Faculdade de Direito da Universidade de São Paulo, São Paulo, v. 89, p. 11-67, jan./dez. 1994.

SALGADO, Graça (Coord.). Fiscais e meirinhos: a administração no Brasil Colonial. Rio de Janeiro: Nova Fronteira, 1985.

SILVA, José Justino de Andrade e. Collecção chronologica da legislação portugueza (1603-1612), Lisboa: Impr. F. X. de Souza, 1854. 11 v.

VIEIRA, Antônio. Sermões. Lisboa: Lello \& Irmão, 1951. v. 3.

WEHLING, Arno; WEHLING, Maria José Cavalheiro de Macedo. Direito e justiça no Brasil Colonial: o Tribunal da Relação do Rio de Janeiro, 1751-1808. Rio de Janeiro: Renovar, 2004. 